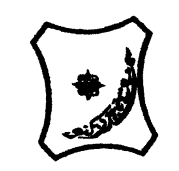

Bayero Journal of Pure and Applied Sciences, 13(1): 97 - 107

Received: April, 2020

Accepted: June, 2020

ISSN 2006 - 6996

\title{
SOURCE ORIGIN AND PALEOENVIRONMENT OF ORGANIC MATTERIN THE TURONIAN SEDIMENTS OF YOLA SUB-BASIN,NORTHERN BENUE TROUGH, NIGERIA: INTEGRATED MOLECULAR AND ELEMENTAL GEOCHEMICAL APPROACH
}

\author{
Sarki Yandoka ${ }^{1 *}$,B. M., Kwaya ${ }^{1}$, M. Y., Ayuba ${ }^{3}$, M.K. \\ ${ }^{1}$ Department of Geology, Bayero University P.M.B. 3011, Kano State - Nigeria \\ ${ }^{2}$ Bioresource Research Centre, N.B.R.D.A, Bayero University Kano, Nigeria \\ Corresponding author: bmsydgombe@gmail.com
}

\begin{abstract}
The Turonian sediments of Yola Sub-basin(the Jessu Formation) formed part of the stratigraphic sequence of the Northern Benue Trough. The sediments were believed to have been deposited in shallow marine environment. Integrated molecular (biological markers) and elemental geochemistry (mineralogical, major and trace elements)were conducted on the Turonian sediments of Jessu Formation with the aim to determine the provenance (source origin) and paleodepositional conditions of organic matter within the sediments. Biomarker parameters such as n-alkanes, isoprenoids, tricyclic and tetracyclic terpanes, regular steranes and diasteranes suggests a significant contribution of both terrigenous and aquatic organic matter input and suboxic paleodepositional condition with low salinity stratified water column and moderate preservation. Elemental geochemistry shows quartz as the most dominant mineral followed by kaolinite, glauconite, montmorillonite, pyrite, illite, chlorite, hematite and calcite whilst major elements are dominated by SiO2, Al203, Fe203, K2O, CaO, MgO, Na2O, TiO, P2O and MnO suggesting terrigeneus origin and continental shallow marine environment. Trace elements concentration within the samples shows presence of $\mathrm{Ba}, \mathrm{V}, \mathrm{Rb}, \mathrm{Sr}, \mathrm{Ni}, \mathrm{Cr}, \mathrm{Ga}$ and $\mathrm{Cu}$ indicative of seawater and suboxic to relatively anoxic marine environment. However, the organic matter within the Turonian sediments of Jessu Formation were sourced mainly from terrigeneous and aquatic and, deposited under suboxic condition in marine setting.
\end{abstract}

Keywords: Provenance; Paleodepositional; Biomarker; Major elements; Trace elements

\section{INTRODUCTION}

Molecular biomarkers are sedimentary organic compounds whose basic skeletons suggest an unambiguous link with known contemporary natural products, and were synthesized by biota present at the time of the deposition of the sediment (Peters et al., 2005). Lipids derived from organisms contributing organic matter to depositional environments can be preserve in the sedimentary record where they can act as biological markers for both the organisms and the environmental conditions prevailing at the time of deposition (Peters and Moldowan, 1993; Peters et al., 2005; Hakimi et al., 2011). Biomarkers can provide valuable information which includes the biological source organisms that generated the organic matter, the environmental conditions that prevailed in the water column and the thermal history of both the rock and the oil, and the degree of microbial biodegradation (Peters et al., 2005).

Inorganic geochemistry of elements and signatures of sedimentary rocks are the product of numerous factors such as mineral composition, climate and tectonism (Johnson, 1993), and are used to give insight to the origin, type, preservation of organic matter and environmental conditions.Major and trace elements are powerful tools used in sedimentology and petroleum geology for better prediction of paleodepositional setting (Adegoke et al., 2014, 2015). Integration of molecular geochemistry biomarkers and elemental geochemistry could revealed meaningful information related to paleodepositional condition, source origin or provenance and overall synthesis of paleodepositional environment (Hakimi et al., 2013).

The Turonian sequences in Yola Sub-basin (Fig. 1) consists of sediments of Jessu Formation. The Jessu Formation is a brief regressive sequences deposited during the Turonian as reported by Carter et al.(1963), Nwajide, (2013), Abubakar, (2014), Sarki Yandoka, (2015), Sarki Yandoka et al. (2014, 2015, 2017) and many others. 
BAJOPAS Volume 13 Number 1, June, 2020

The formation was conformably overlain by marine (shelf) Sekuliye Formation and underlain by marine (?carbonate ramp) Dukul Formation. Sedimentology and geochemistry studies had earlier been carried out on the Turonian sediments (e.g. Carter et al., 1963; Abubakar, 2006; Sarki Yandoka, 2019) but there is no any reported work on integrated sedimentary biomarkers and elemental geochemistry on the sediments. This paper however, presented an integrated study on organic and inorganic geochemistry to suggest the paleo-redox condition, source origin or provenance, paleodepositional setting, paleoclimatic condition and tectonic setting during sedimentation of the Turonian sequences of Yola Sub-basin.

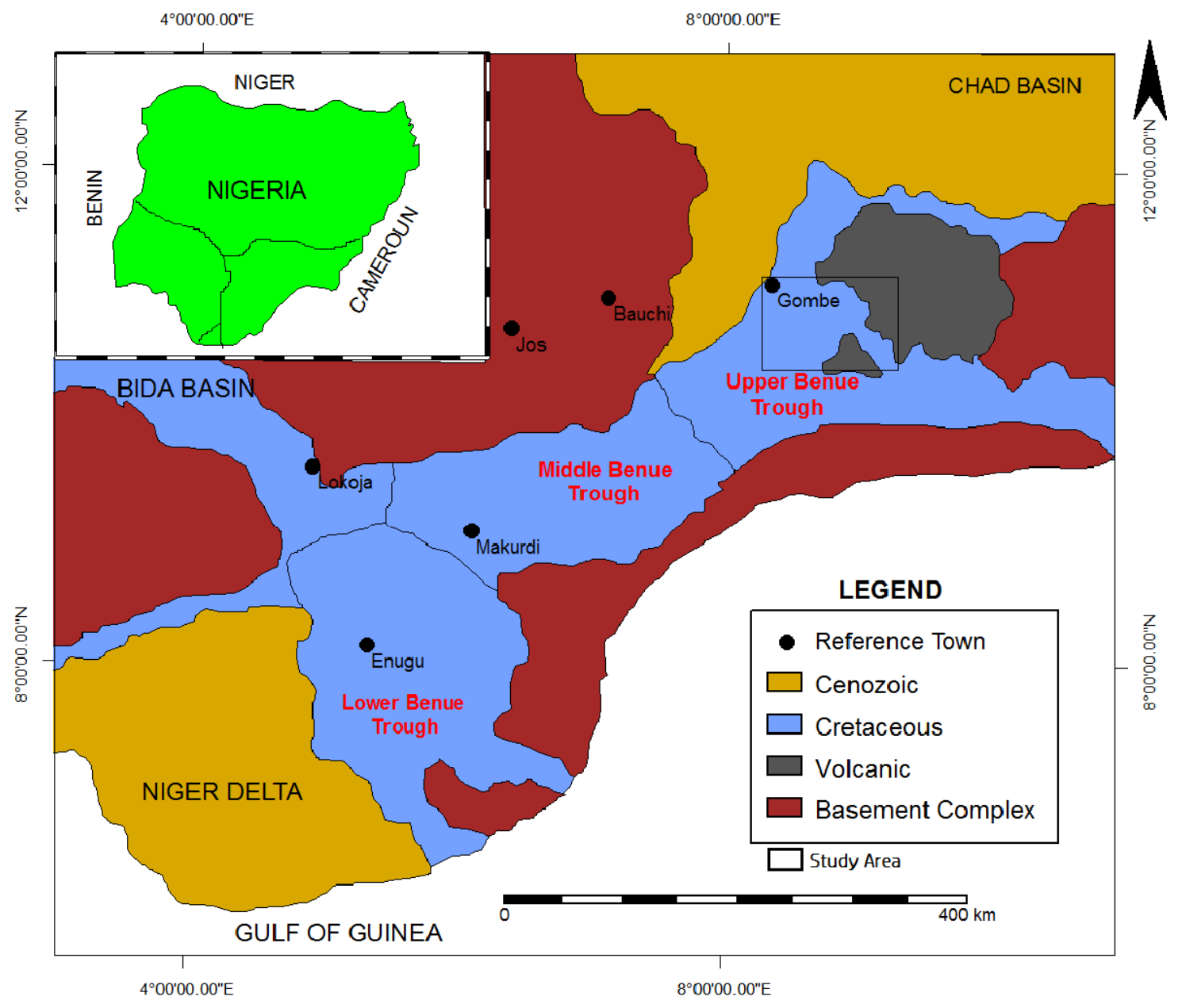

Figure 1: Regional geological map showing the Nigerian Benue Trough and study area in black box (modified after Abubakar, 2014)

\section{Geology of the area}

Several lines of evidence suggest that the entire Benue Trough forms part of the larger West and Central African Rift System basins that developed as a consequence of separation of the African and South American Plates during the Jurassic times (Genik, 1992; Guiraud, 1990). The Aptian-Albian syn-rift to post-rift fluvial to lacustrine successions of the continental Bima Formation forms the oldest sedimentary unit in the Yola Sub-basin, directly overlying the Basement Complex Rocks (Fig. 2) (Guiraud, 1990; Guiraud and Maurin, 1992; Sarki Yandoka et al., 2014). With the commencement of midCretaceous global marine transgression during the Cenomanian, the transitional-marine deposits of the Yolde Formation were deposited conformably on the continental units (Sarki Yandoka, 2015). 


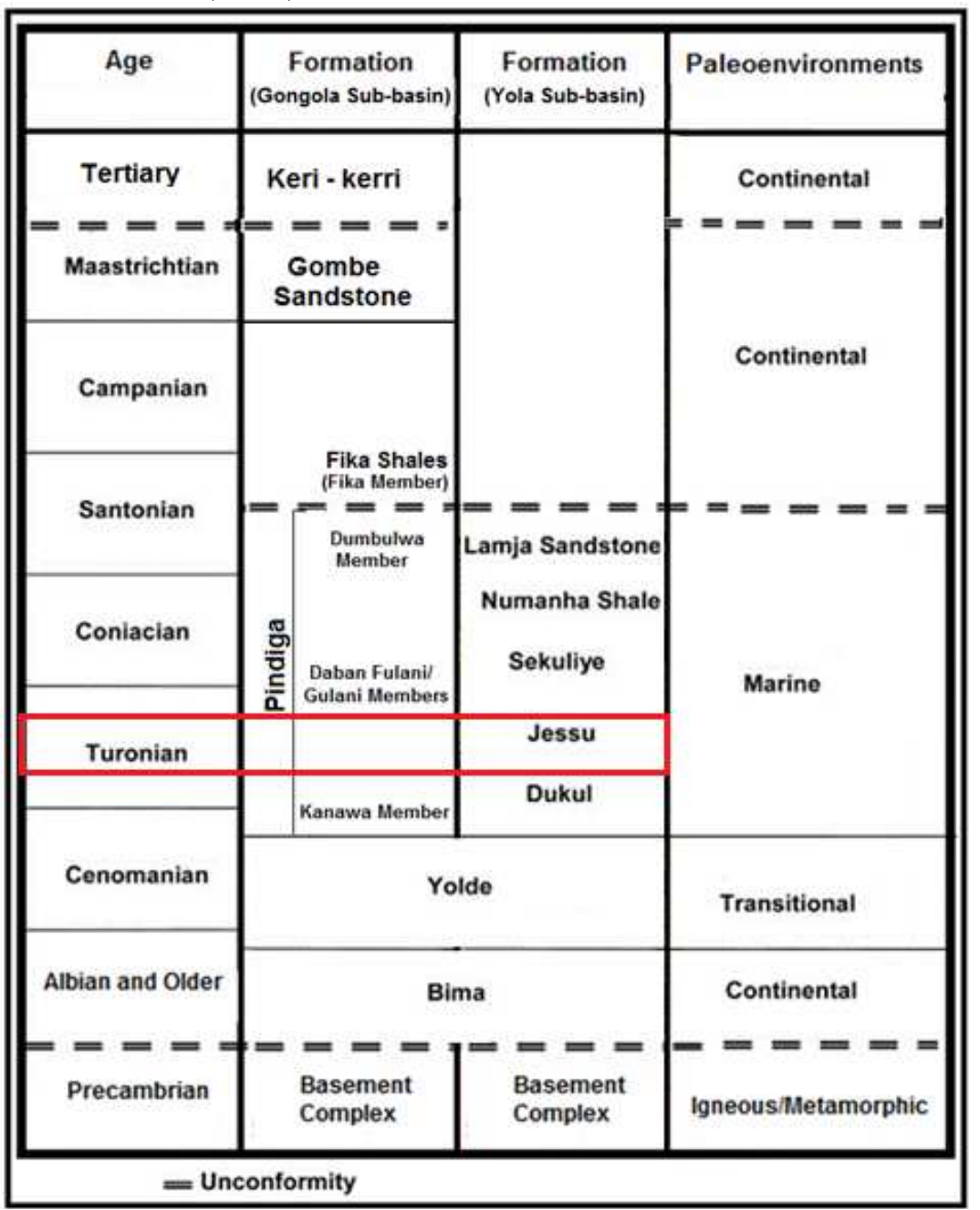

Figure 2: Stratigraphic sequence of Northern Benue Trough showing the Turonian sediments (modified after Abubakar, 2006)

The peak of this transgressive phase in the Turonian led to the deposition of the shallow marine shales and limestones of the Dukul Formation (Sarki Yandoka, 2015), and following a relative sea level fall in the mid-Turonian, the regressive Jessu Formationwas deposited (Nwajide, 2013) (Fig. 2). Renewed surge in the late Turonian through theConiacian and early Santonian deposited the deep marine blue-black shales of the Sekuliye and Numanha (Shale) Formations that characterizes the topmost units of the marine sequences in the basin (Sarki Yandoka, 2015). This incursion is accompanied by a compressional tectonic pulse in the midSantonianthat resulted from change in displacement vectors between the African plate and European/Tethys plates (Guiraud and Maurin, 1992; Benkhelil, 1989).

This activity thrusted the pre-Maastrichtian sediments westwards to the Gongola Sub basin. This creates a depositional locus that built out the ?Campano-Maastrichtian regressive deltaic packages of the Lamja Formation which marked the end of sedimentation in the basin (Carter et al. 1963). The mid-Maastrichtian experienced a folding event, and was subsequently followed by thermotectonic sagging (Abubakar, 2014; Zarborski et al., 1997). The volcanics occur as localized sills and plugs across the sedimentary fill of the Yola Sub-basin (Guiraud and Maurin, 1992; Sarki Yandoka, 2019).

The regressive sequences of Jessu Formation (Fig. 2), the subject of this study, consists of alternating sequence of grey white and brown shales and light brown sandy mudstones with subordinate sandstones (Carter et al., 1963). Sandy mudstones are predominant in the lower part. The beds indicate a a brief return to the "passage beds" type of sedimentation of the transitional Yolde Formation (Sarki Yandoka et al., 2015). The formation was considered to have being deposited during Upper Turonian and conformably overlies Dukul Formation (Nwajide, 2013; Sarki Yandoka et al., 2019). 


\section{MATERIALS AND METHODS}

Geological fieldwork was conducted on the exposed sediments within the Yola Sub-basin. Ten (10) shale samples were collected (Fig. 3) using channel sampling after removing the weathering surfaces by digging to about $0.5 \mathrm{~m}$. All samples were crushed to less than 200 meshes. About $12 \mathrm{~g}$ of each sample was subjected to bitumen extraction with Soxhlet apparatus for 72 hours using an azeotropic mixture of dichloromethane (DCM) and methanol $(\mathrm{CH} 3 \mathrm{OH})(93: 7)$. The extracts were separated into saturates, aromatics and NSO (nitrogen, sulfur and oxygen) compounds by liquid-column chromatography. The saturate fractions were dissolved in hexane and analyzed by a gas chromatography-mass spectrometry (GC-MS) on a HP 5975B MSD mass spectrometer with a gas chromatograph attached directly to the ion source $(70 \mathrm{eV}$ voltage, 100 milliamps filament emission current, $230 \mathrm{oC}$ interface temperature). The fingerprints of the GC-MS analysis was used to study sedimentary biomarkers e.g. normal alkanes and isoprenoids, terpanes and steranes.

About $0.50 \mathrm{~g}$ of each sample was prepared for non-destructive wavelength dispersive X-ray fluorescence spectrometer (PANalyticalAxiosmAX $4 \mathrm{KW}$ sequential XRF spectrometer). The XRF analysis was used to determine the concentration of oxides of major elements. About $0.50 \mathrm{~g}$ of each sample was weighed in a Teflon beaker and dried at $105^{\circ} \mathrm{C}$ overnight. The dried samples were moistened with a few $\mathrm{ml}$ of deionized water. $5 \mathrm{ml}$ of Nitric acid $\left(\mathrm{HNO}_{3}\right)$ was slowly added and placed on hotplate at $150^{\circ} \mathrm{C}$, followed $10 \mathrm{ml}$ of hydrofluoric acid (HF) and $4 \mathrm{ml}$ of perchloric acid $\left(\mathrm{HClO}_{4}\right)$. The samples were digested with $10 \mathrm{ml}$ of $5 \mathrm{M} \mathrm{HNO}_{3}$ in a fume hood. The solutions were diluted with deionized water to $50 \mathrm{ml}$ in a volumetric flask. All the digested samples were diluted up to 100 times with ultimate pure water (UPW). Standard solutions of the elements with an analyte concentration of $10 \mathrm{ppm}$ were used for calibration with a minimum detection limit of less than $1 \mathrm{ppb}$. The trace and rare earth elements were determined using Agilent Technologies 7500 Series Inductively-coupled plasma mass spectrometer (ICP-MS). All analyses were carried out at Geochemistry Section, Department of Geology, University of Malaya, Kuala Lumpur-Malaysia.

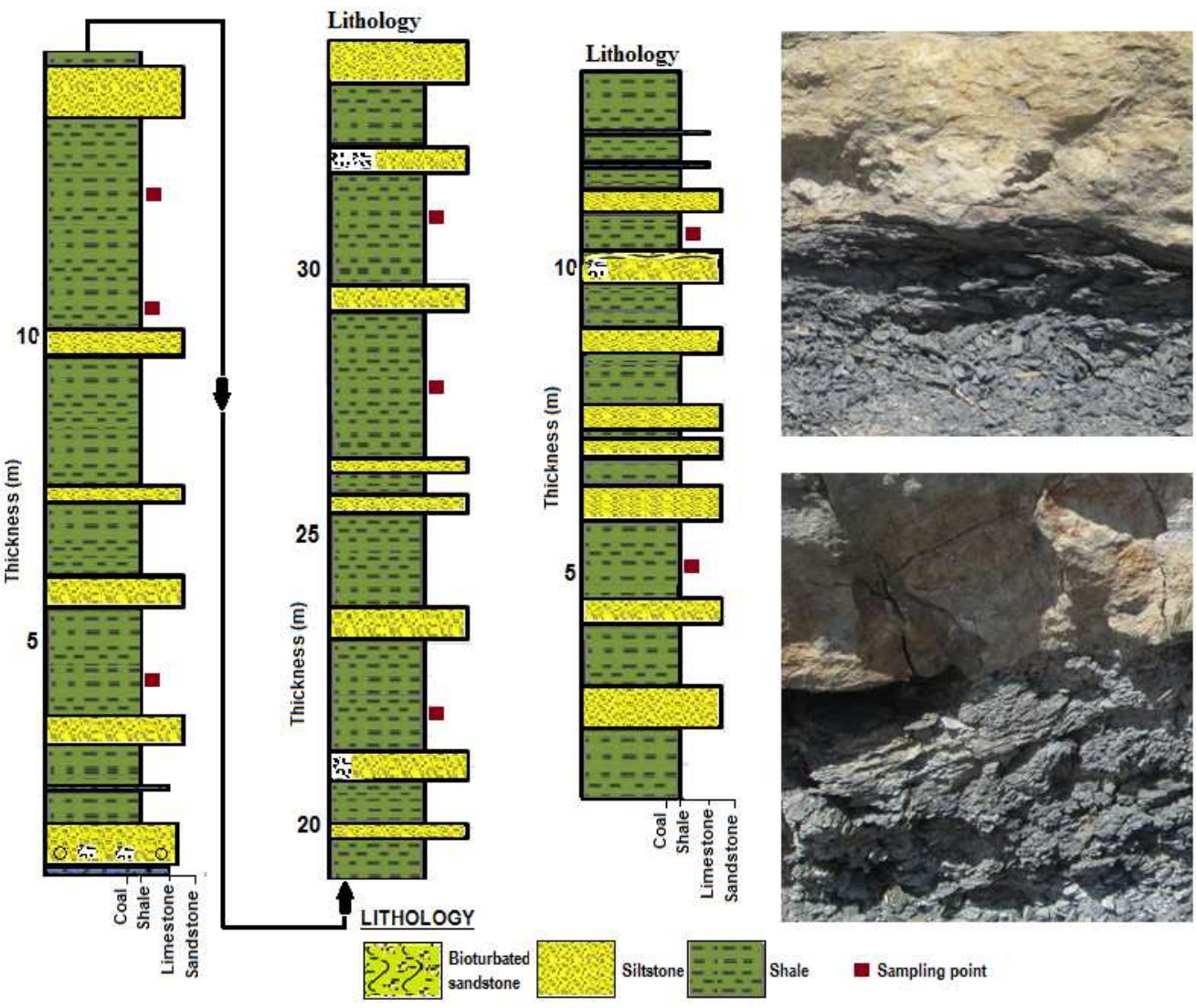

Figure 3: Sedimentary logs and field photos depicting the sampling horizons 
BAJOPAS Volume 13 Number 1, June, 2020

RESULTS AND DISCUSSIONS

Gas chromatography-mass spectrometry (GC-MS) analysis

The $m / z \quad 85$ mass fragmentograms of the saturated hydrocarbon fractions are characterized by high amounts of n-alkanes and isoprenoids, which display prominent distributions between $n-C_{12}-n-C_{30} n$-alkanes and isoprenoids hydrocarbons with both low and higher molecular weight compounds and dominance of $n-C_{14}-n-C_{33}$. Pristane is generally occurring in high relative concentrations possessing pristane/phytane ( $\mathrm{Pr} / \mathrm{Ph})$ ratios in the range of 1.0-2.8 (Tables 1 and 2; Fig. 4). The higher amounts of n-alkanes compared to isoprenoids gave relatively low pristane/n- $C_{17}$ and phytane/n- $\mathrm{C}_{18}$ ratios in the range of $0.33-$ 1.23 and $0.20-1.22$, respectively. The analysed shales possess low to moderate waxiness index values in the range of $0.29-1.60$ while CPI values range from $0.60-1.14$.
The m/z 191 mass fragmentograms (Fig. 4) show that the hopanoids are dominated by the presence of $\mathrm{C}_{30}$-hopane, $\mathrm{C}_{29}$-norhpane, $17 \mathrm{a}(\mathrm{H})$ trisnorhopane (Tm) and 18a-22,29,30trisnorneohopane (Ts), with significant amounts of tricyclic and tetracyclic terpanes and a considerable quantity of homohopanes $\left(\mathrm{C}_{31}-\mathrm{C}_{33}\right)$. The relative abundance of $\mathrm{C}_{29}$-norhopane is greater than $\mathrm{C}_{30}$-hopane with $\mathrm{C}_{29} / \mathrm{C}_{30} \quad 17 \mathrm{a}(\mathrm{H})$ hopane ratio ranging from 0.78-3.04 (Table 2). The concentration of tricyclic and tetracyclic terpanes is present in significant amounts with high values of the $C_{24}$ tetracyclic to $C_{26}$ tricyclic ratios $\left(C_{24} T e / C_{26} T\right)$ in the range between 1.36 and 5.30 while gammacerane index (G/C30) ranges from $0.02-0.36$. The $17 \beta, 21 a(H)-$ moretane was detected in low concentration. The relative proportion of regular steranes $\left(C_{27}\right.$, $\mathrm{C}_{28}$ and $\mathrm{C}_{29}$ ) based on $\mathrm{m} / \mathrm{z} 217$ shows high concentration of $\mathrm{C}_{29} \quad(32.7-64.0 \%)$ regular steranes compared to $\mathrm{C}_{27}(15.0-51.2 \%)$ and $\mathrm{C}_{28}$ (14.0-25.7\%) respectively (Table 2 ).

Table 1:Ratios of $\mathbf{n}$ - alkanes, isoprenoids and hopanes distributions

\begin{tabular}{|c|c|c|c|c|c|c|c|c|c|c|c|}
\hline \multirow{2}{*}{$\begin{array}{l}\text { 当 } \\
\frac{0}{\bar{B}} \\
\text { : }\end{array}$} & \multicolumn{5}{|c|}{$n$ - alkanes and acyclic isopren oids } & \multirow[b]{2}{*}{$\begin{array}{l}\mathrm{C}_{29} / \\
\mathrm{C}_{30}\end{array}$} & \multicolumn{5}{|c|}{ Hopane } \\
\hline & $\begin{array}{l}\mathrm{Pr} / \\
\mathrm{Ph}\end{array}$ & $\begin{array}{c}\mathrm{Pr} / n- \\
\mathrm{C}_{17}\end{array}$ & $\begin{array}{c}\mathrm{Pr} / n- \\
\mathrm{C}_{18}\end{array}$ & CPI & WI & & $\begin{array}{c}\mathrm{C}_{3122} 22 \\
\mathrm{R} / \mathrm{C}_{30} \\
\mathbf{H}\end{array}$ & $\begin{array}{c}\mathbf{G} / \mathbf{C} \\
30\end{array}$ & $\begin{array}{c}\mathrm{C}_{32} 22 \mathrm{~S} / \\
(22 \mathrm{~S}+ \\
22 \mathrm{R})\end{array}$ & $\begin{array}{c}\mathrm{MC}_{30} / \\
\mathrm{HC}_{30}\end{array}$ & $\begin{array}{c}\text { Tm/ } \\
\text { Ts }\end{array}$ \\
\hline Ll & 1.85 & 0.88 & 0.44 & 1.06 & 1.60 & 2.05 & 0.40 & 0.12 & 0.68 & 0.04 & 0.46 \\
\hline L2 & 1.63 & 0.44 & 0.32 & 1.14 & 0.53 & 2.22 & 0.31 & 0.08 & 0.66 & 0.20 & 0.45 \\
\hline L3 & 1.75 & 0.86 & 0.40 & 1.09 & 1.43 & 3.04 & 0.28 & 0.06 & 0.72 & 0.23 & 0.47 \\
\hline L4 & 1.12 & 0.54 & 0.41 & 1.13 & 1.34 & 2.09 & 0.26 & 0.02 & 0.62 & 0.16 & 0.34 \\
\hline L5 & 1.32 & 0.73 & 0.43 & 1.09 & 0.92 & 2.34 & 0.28 & 0.03 & 0.70 & 0.15 & 0.37 \\
\hline L6 & 1.70 & 0.47 & 0.30 & 1.0 & 0.60 & 1.47 & 0.28 & 0.06 & 0.61 & 0.43 & 0.14 \\
\hline L7 & 2.21 & 0.96 & 0.45 & 1.03 & 0.85 & 1.56 & 0.28 & 0.10 & 0.60 & 0.45 & 0.18 \\
\hline L8 & 1.22 & 1.03 & 0.75 & 1.0 & 1.11 & 1.60 & 0.27 & 0.15 & 0.61 & 0.39 & 0.11 \\
\hline
\end{tabular}

Table 2:Ratios of Terpanes, steranes and diasteranes distributions

\begin{tabular}{|c|c|c|c|c|c|c|c|c|c|c|c|c|}
\hline \multirow{3}{*}{ 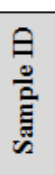 } & \multicolumn{6}{|c|}{ Tricyclic (T) and Tetracyclic (Te) terpanes } & \multicolumn{6}{|c|}{ Steranes and diasteranes $(\mathrm{m} / \mathrm{z} 217)$} \\
\hline & \multirow{2}{*}{$\begin{array}{l}\mathrm{C}_{21} \mathbf{T} / \\
\mathrm{C}_{23} \mathbf{T}\end{array}$} & \multirow{2}{*}{$\begin{array}{l}\mathrm{C}_{22} \mathbf{T} / \\
\mathrm{C}_{21} \mathbf{T}\end{array}$} & \multirow{2}{*}{$\begin{array}{l}\mathrm{C}_{24} \mathrm{~T} / \\
\mathrm{C}_{23} \mathrm{~T}\end{array}$} & \multirow{2}{*}{$\begin{array}{l}\mathrm{C}_{24} \mathrm{Te} \\
/ \mathrm{C}_{26} \mathrm{~T}\end{array}$} & \multirow{2}{*}{$\begin{array}{l}\mathrm{C}_{23} \mathrm{~T} / \\
\mathrm{C}_{24} \mathrm{~T}\end{array}$} & \multirow{2}{*}{$\begin{array}{l}\mathrm{C}_{23} \mathrm{~T} / \\
\mathrm{C}_{24} \mathrm{Te}\end{array}$} & \multirow{2}{*}{$\begin{array}{c}\mathrm{C}_{29} 20 \mathrm{~S} / \\
20 \mathrm{~S}+20 \mathrm{R}\end{array}$} & \multirow{2}{*}{$\begin{array}{l}\mathrm{C}_{29} \beta \beta / \\
\beta \beta+\alpha \alpha\end{array}$} & \multicolumn{3}{|c|}{ Regular steranes (\%) } & \multirow{2}{*}{$\begin{array}{l}\mathrm{C}_{29} / \\
\mathrm{C}_{27}\end{array}$} \\
\hline & & & & & & & & & $\mathrm{C}_{27}$ & $\mathrm{C}_{28}$ & $\mathrm{C}_{29}$ & \\
\hline Ll & 0.84 & 0.33 & 0.34 & 1.36 & 2.98 & 0.42 & 0.34 & 0.59 & 15.0 & 20.9 & 64.0 & 3.39 \\
\hline L2 & 0.83 & 0.31 & 0.38 & 2.10 & 2.57 & 0.59 & 0.42 & 0.70 & 51.2 & 16.1 & 32.7 & 0.64 \\
\hline L3 & 0.91 & 0.55 & 0.32 & 1.8 & 3.14 & 0.35 & ------ & ------ & $-\cdots$ & 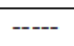 & ----- & $-\cdots$ \\
\hline L4 & 0.60 & 0.23 & 0.52 & 2.08 & 1.91 & 1.35 & 0.41 & 0.62 & 31.9 & 20.4 & 47.7 & 1.49 \\
\hline L5 & 0.68 & 0.28 & 0.45 & 1.91 & 2.23 & 0.98 & 0.42 & 0.64 & 28.1 & 24.5 & 47.4 & 1.23 \\
\hline L6 & 1.17 & 0.32 & 0.52 & 2.33 & 1.93 & 0.69 & 0.32 & 0.62 & 28.5 & 21.3 & 50.2 & 1.76 \\
\hline L7 & 1.36 & 0.46 & 0.63 & 2.36 & 1.58 & 0.73 & 0.31 & 0.52 & 27.4 & 21.7 & 50.9 & 1.86 \\
\hline L8 & 1.13 & 0.29 & 0.48 & 2.47 & 2.04 & 1.64 & 0.37 & 0.54 & 40.5 & 18.8 & 40.7 & 1.02 \\
\hline
\end{tabular}



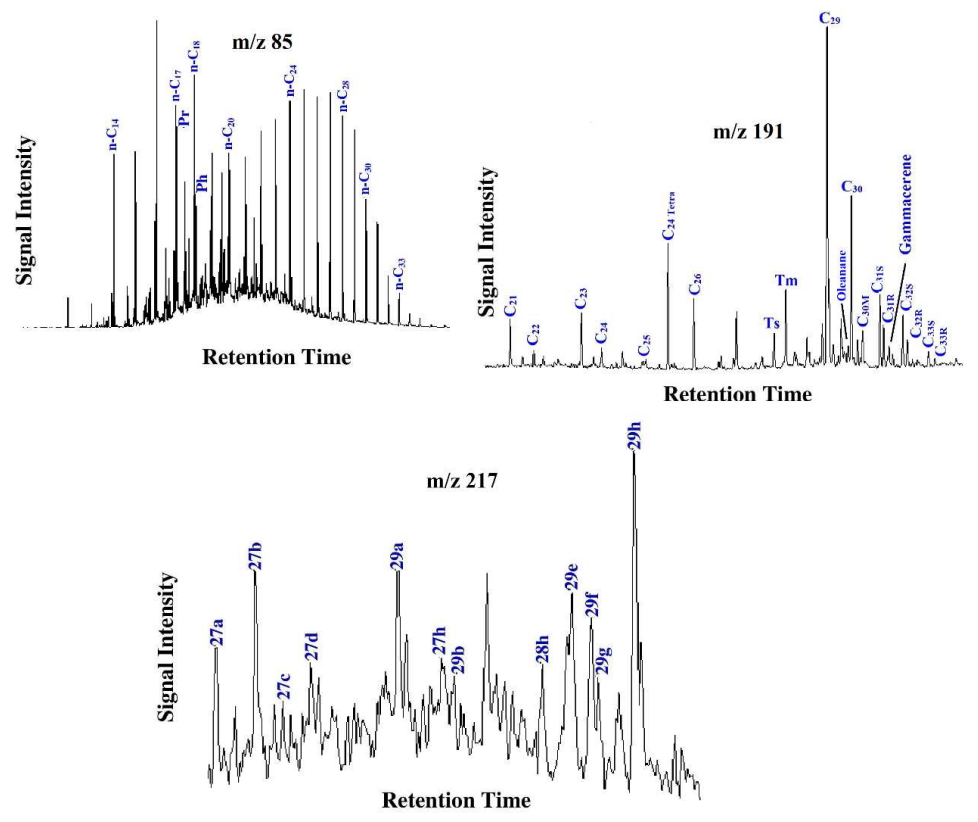

Figure 4: Representative of mass fragmentogram of $\mathrm{m} / \mathrm{z} 85, \mathrm{~m} / \mathrm{z} 191$ and $\mathrm{m} / \mathrm{z} 217$ of the saturated hydrocarbon for the studied samples

$X$-ray diffraction and X-ray fluorescence analyses

X-ray diffraction (XRD) and X-ray fluorescence (XRF) analyses were conducted for mineralogical and major elements determination (Table 3; Fig. 5). For XRD analysis, quartz is the most dominant mineral followed by kaolinite, glauconite, montmorillonite, pyrite, illite, chlorite, hematite and calcite. The oxides of major elements are dominated by $\mathrm{SiO}_{2}$ (av. 54.4\%), $\mathrm{Al} 2 \mathrm{O} 3$ (av. 12.7\%), Fe2O3 (av. 6.4\%), and $\mathrm{K} 2 \mathrm{O}$ (av. 3.1\%) while others ( $\mathrm{CaO} \%$, $\mathrm{MgO} \%, \mathrm{Na} 2 \mathrm{O} \%$, $\mathrm{TiO} \%$, $\mathrm{P} 2 \mathrm{O} 5 \%, \mathrm{MnO} \%$ ) have concentration of mostly $<1.0 \%$ (Table 3 ). The XRD results are generally compatible with the chemical analysis data and the mineralogical variation agreed with the major element compositions.

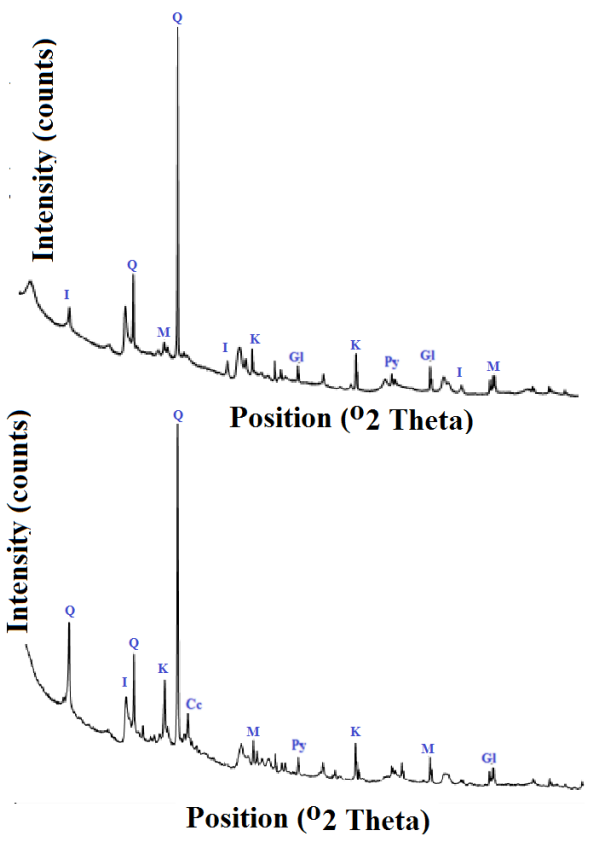

Figure 5: X-ray diffractograms showing Q-Quartz, Py- Pyrite, F-Feldspar, I-Illite, MMontmorillonite, Cc-Calcium carbonate, K-Kaolinite, F- Feldspar, Gl- Glauconite, HHematite and B- Barite 
BAJOPAS Volume 13 Number 1, June, 2020

Table 3: Oxides of major elements based on XRF analysis

\begin{tabular}{|l|cc|c|c|c|c|c|c|c|}
\hline \multirow{2}{*}{$\begin{array}{c}\text { Sample } \\
\text { ID }\end{array}$} & \multicolumn{8}{|c|}{ Oxides of major elements (wt. \%) } \\
\cline { 2 - 11 } & $\mathbf{S i O}_{\mathbf{2}}$ & $\mathbf{A l}_{\mathbf{2}} \mathbf{O}_{\mathbf{3}}$ & $\mathbf{T i O}_{\mathbf{2}}$ & $\mathbf{F e}_{\mathbf{2}} \mathbf{O}_{\mathbf{3}}$ & $\mathbf{P}_{\mathbf{2}} \mathbf{O}_{\mathbf{5}}$ & $\mathbf{C a O}$ & $\mathbf{M g O}$ & $\mathbf{N a}_{\mathbf{2}} \mathbf{O}$ & $\mathbf{K}_{\mathbf{2}} \mathbf{O}$ \\
\hline $\mathbf{L 1}$ & 54.8 & 12.8 & 0.67 & 5.67 & 0.20 & 0.62 & 0.56 & 0.22 & 2.96 \\
$\mathbf{L 2}$ & 59.0 & 10.2 & 0.65 & 6.18 & 0.18 & 0.41 & 0.62 & 0.23 & 2.98 \\
\hline $\mathbf{L 3}$ & 52.6 & 15.6 & 0.76 & 6.21 & 0.39 & 0.45 & 0.60 & 0.30 & 3.32 \\
\hline L4 & $\mathbf{5 2 . 9}$ & 11.5 & 0.68 & 6.34 & 0.15 & 0.56 & 0.62 & 0.28 & 3.11 \\
\hline L5 & 51.2 & 12.6 & 0.77 & 6.51 & 0.35 & 0.44 & 0.59 & 0.22 & 3.12 \\
\hline L6 & 50.4 & 13.9 & 0.79 & 5.82 & 0.16 & 0.51 & 0.57 & 0.23 & 2.98 \\
\hline L7 & 49.8 & 11.4 & 0.64 & 6.62 & 0.23 & 0.37 & 0.58 & 0.27 & 3.21 \\
\hline L8 & 54.8 & 12.8 & 0.67 & 5.67 & 0.20 & 0.62 & 0.56 & 0.22 & 2.96 \\
\hline
\end{tabular}

The contents of $\mathrm{SiO} 2$ may be caused by the interbedding of sandstones and mudstones (Sarki Yandoka, 2015). This is consistent with interbedded mudstone and sandstone associated with the sediments (Fig. 3). The Al2O3 concentration is high and this is related to the presence of clay minerals such as kaolinite and illite clay minerals that were observed in the samples by XRD analysis (Fig. 5).TiO2 originates mostly from a mixed clay assemblage, consistent with the occurrence of kaolinite and illite clay minerals. The high $\mathrm{CaO}$ concentration is explained by the presence carbonate mineral and glauconite that were observed in the samples based on XRD analysis (Fig. 5). MgO concentration is due to the enrichment of carbonates while $\mathrm{K} 2 \mathrm{O}$ concentration is mainly attributed to the presence of illite clays in the samples.

\section{Inductively coupled plasma mass} spectrometry (ICPMS) analysis

The trace elements concentration show $\mathrm{Ba}, \mathrm{V}$, $\mathrm{Rb}, \mathrm{Sr}$ and $\mathrm{Ni}$ with average values of 114.0, 53.5, 36.3, 26.1 and 9.2 ppm respectively, while $\mathrm{Cr}, \mathrm{Ga}$ and $\mathrm{Cu}$ have average values of 15.0, 15.6 and 5.4 ppm respectively. High concentration of trace elements such as $\mathrm{Ba}, \mathrm{Sr}, \mathrm{Rb}$ and $\mathrm{V}$ are indicative of seawater rather than freshwater (Sarki Yandoka et al., 2015). V is usually enriched in comparison with $\mathrm{Ni}$ in anoxic marine environments (Peters and Moldowan, 1993).Co is usually enriched in comparison with $\mathrm{Ni}$ in oxic conditions. The $\mathrm{Cr}$ is usually enriched in comparison with $\mathrm{V}$ in oxic conditions. Manganese (Mn) forms highly insoluble $\mathrm{Mn3}+$ or $\mathrm{Mn4+}$ hydroxides or oxides under oxic conditions, while during reducing conditions, is reduced to $\mathrm{Mn2}+$ and forms soluble $\mathrm{Mn2}+$ or $\mathrm{MnCl}+$ cations, which can be dissolved within bottom sediments and diffuse into the overlying anoxic water column, where $\mathrm{MnCO} 3$ precipitation may occur, so that manganese concentrations in the seawater are depleted.

Table 4: Concentration of trace elements based on ICP-MS analysis

\begin{tabular}{|c|c|c|c|c|c|c|c|c|c|c|c|c|c|}
\hline \multirow{2}{*}{$\begin{array}{l}\text { Sample } \\
\text { ID }\end{array}$} & \multicolumn{13}{|c|}{ Trace elements (ppm) } \\
\hline & $\mathbf{V}$ & $\mathrm{Ni}$ & $\mathrm{Cu}$ & $\mathrm{Cr}$ & $\mathrm{Sr}$ & $\mathrm{Ba}$ & $\mathbf{R} \mathbf{b}$ & Ga & Co & Sc & $\mathrm{Ni} / \mathrm{Co}$ & $\mathrm{V} / \mathrm{Sc}$ & $\mathrm{Sr} / \mathrm{Ba}$ \\
\hline L1 & 46.9 & 5.4 & 5.60 & 13.6 & 34.6 & 116 & 45.6 & 14.2 & 1.1 & 2.4 & 4.91 & 20.3 & 0.30 \\
\hline L3 & 64.8 & 12.7 & 6.12 & 13.4 & 17.6 & 111 & 34.4 & 21.3 & 2.4 & 3.0 & 5.30 & 22.6 & 0.16 \\
\hline L4 & 43.6 & 11.2 & 6.11 & 12.6 & 19.0 & 119 & 37.1 & 16.4 & 2.2 & 2.1 & 5.01 & 20.7 & 0.16 \\
\hline L7 & 67.7 & 7.9 & 6.30 & 16.4 & 31.6 & 118 & 42.4 & 18.5 & 1.3 & 4.2 & 6.07 & 16.1 & 0.27 \\
\hline L8 & 48.9 & 5.4 & 5.60 & 13.6 & 34.6 & 116 & 45.6 & 14.2 & 1.1 & 2.4 & 4.91 & 20.3 & 0.30 \\
\hline
\end{tabular}

\section{Source origin (Terristrial vs Aquatic)}

The n-alkanes patterns of the Jessu shales are characterised by significant short ( $n-C 14-n-C 20)$ to middle (n-C21-n-C23)-chain n-alkanes and long-chain alkanes ( $+n-C 23)$. This suggests a significant contribution of both terrigenous and aquatic organic matter input. This interpretation is supported by low waxiness index ratios (Table 1). The $\mathrm{Pr} / \mathrm{Ph}$ ratios, $\mathrm{pr} / \mathrm{n}-\mathrm{C} 17$ and $\mathrm{ph} / \mathrm{n}-\mathrm{C} 18$ for the shales indicate a mixed organic matter inputs. This is supported by the cross-plot of $\mathrm{pr} / \mathrm{n}-\mathrm{C} 17$ against $\mathrm{ph} / \mathrm{n}-\mathrm{C} 18$ (Fig. 6). 
BAJOPAS Volume 13 Number 1, June, 2020

It is further supported based on waxiness index and the CPI values (Table 1) suggesting both terrigenous and aquatic organic matter source input. The dominance of C27 steranes indicate a preponderance of marine phytoplankton, whereas a dominance of C29 indicate a strong land plant terrestrial contribution and C28 steranes shows a heavy contribution by lacustrine algae (Peters et al. 2005). The samples contain a high contribution of terrestrially derived organic matter with minor aquatic organic matter contributions, which thus display a strong predominance of C29 steranes (Fig. 4). The concentrations of terpanes with the ratios of various tricyclic terpanes have also indicated mixed marine and terrestrial-derived organic matter (Peters et al., 2005).
Paleoenvironment (Redox condition vs Preservation)

Several factors have been proposed as the primary controls on organic matter burial and preservation in sediments. These includes sedimentary burial rate, clay mineralogy, and water column oxygenation levels (Zonneveld et al., 2010). Biomarker distributions such as nalkanes, acyclic isoprenoids, triterpanes and steranes may provide information about paleoredox conditions and depositional environments of organic matter (Waples and Muchihara, 1991; Hunt, 1995; Peters et al., 2005). Clay minerals, major and trace elements compositions in sediments can also be used to give some insight into the origin, type, redox conditions and preservation of organic matter (Johnson, 1993).

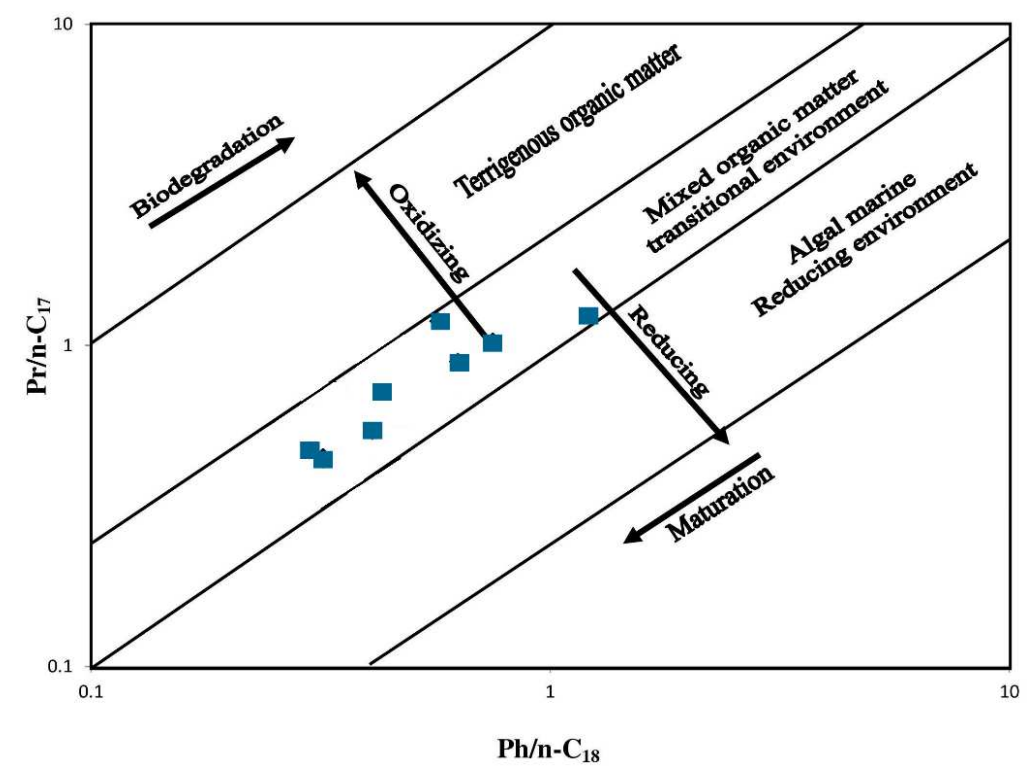

Figure 6:Cross plot of Pristane/n-C17 against Pristane/n-C18 showing the mixed organic matter source inputs (modified after Peters et al., 2005)

The $\mathrm{Pr} / \mathrm{Ph}$ ratios indicate a deposition under suboxic conditions as further supported by cross-plot of $\mathrm{Pr} / \mathrm{n}-\mathrm{C} 17$ and $\mathrm{Ph} / \mathrm{n}-\mathrm{C} 18$ (Fig. 6). The C31-22R-hopane/C30-hopane ratio of the shale samples is in the range of $0.25-0.48$, suggesting that these shales were deposited in a marine environment. The cross plot of $\mathrm{C}_{29} / \mathrm{C}_{27}$ regular sterane against $\mathrm{Pr} / \mathrm{Ph}$ suggests deposition under suboxic condition (Fig. 7). Gammacerane index is an evidence for the existence of low salinity stratified water column during the deposition of the sediments. The data is consistent with $\mathrm{Sr} / \mathrm{Ba}$ ratios. The shale samples have low $\mathrm{Sr} / \mathrm{Ba}$ ratio, indicating low salinity water during sedimentation under environmental condition that was probably mainly suboxic.
The presence of terrestrial detritus elements (e.g., $\mathrm{SiO} 2$ and $\mathrm{TiO} 2$ ) in significant amounts further confirms that the samples are originated from terrestrial not purely from aquatic or marine. Clay minerals such as kaolinite, illite and montmorillonite are present. Therefore, the clay minerals of the studied samples provided physical protection against decay for the organic matter which favoured its preservation (Roy and Roser, 2013).Vanadium (V) and Nickel (Ni) V is usually enriched in comparison with $\mathrm{Ni}$ in anoxic marine environments (Peters and Moldowan, 1993). V/Ni ratio greater than 3 indicates that sediments were deposited in a reducing environment, while $\mathrm{V} / \mathrm{Ni}$ ratios ranging from 1.9 to 3 indicate deposition under suboxic conditions with precursor organic matter of mixed origin (Galarraga et al. 2008). 
BAJOPAS Volume 13 Number 1, June, 2020

The concentration of Vanadium (V) and Nickel (Ni) indicates that the shales were deposited under suboxic conditions. Moreover, the high ratios of hopane/sterane in the analysed shale sediments also support a marine depositional environment. Glauconite is diagnostic of continental shelf environment where sedimentation of clastics and carbonates become slow indicative of low energy environment and interstitial waters become oxygen-deficient (Nichols, 2009).

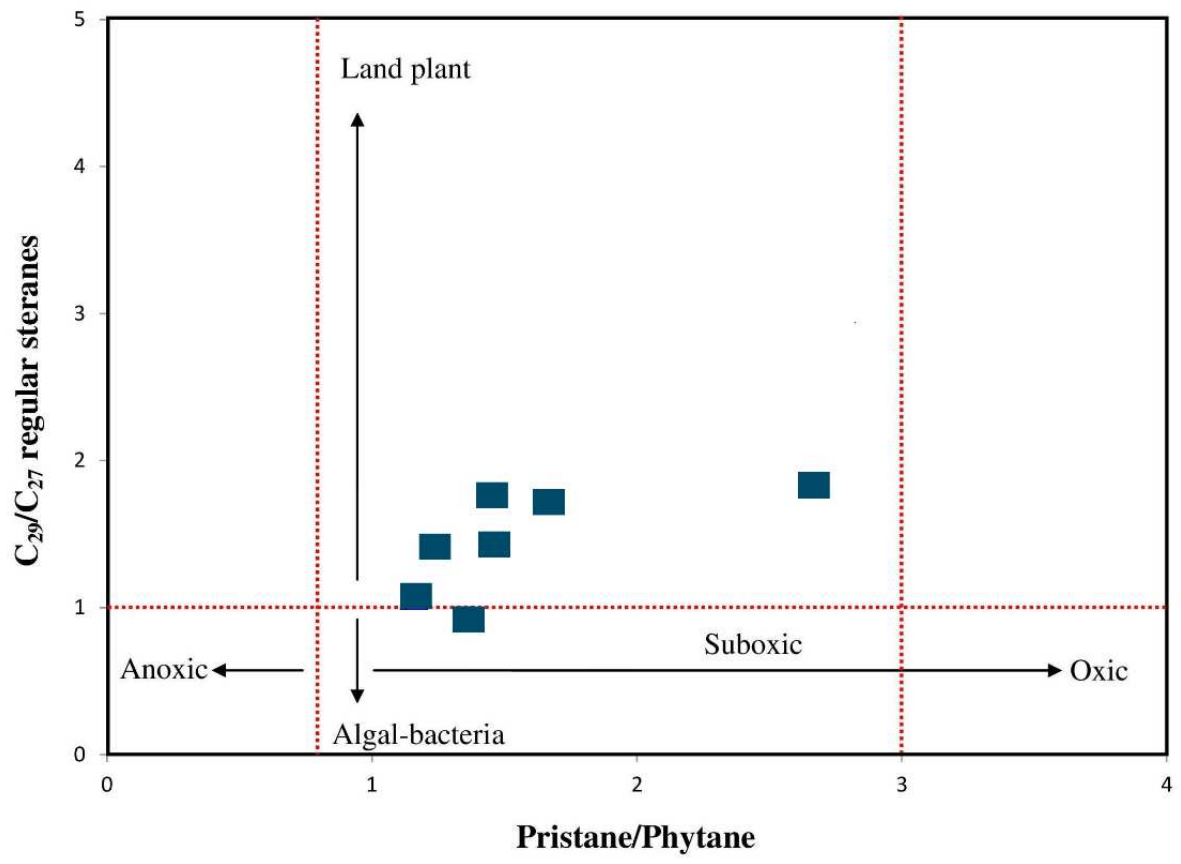

Figure 7: Cross plot of C29/C27 regular steranes against Pristane/Phytane showing the depositional condition (modified after Peters et al., 2005)

\section{CONCLUSIONS}

An integrated molecular and elemental geochemical investigation of Turonian sediments of Jessu Formation of the Northern Benue Trough in order to determine the provenance (source origin) and paleodepositional conditions of organic matter within the sediments suggest that thebiomarker parameters such as $\mathrm{n}$ alkanes, isoprenoids, tricyclic and tetracyclic terpanes, regular steranes and diasteranes further suggests a significant contribution of both terrigenous and aquatic organic matter input and suboxic paleodepositional condition with low salinity stratified water column and moderate preservation. Elemental geochemistry shows quartz as the most dominant mineral

\section{REFERENCES}

Abubakar, M.B., (2006). Biostratigraphy, palaeoenvironments and organic geochemistry of the Cretaceous sequences of the Gongola Basin, Upper Benue Trough, PhD unpublished thesis, Abubakar Tafawa Balewa University Bauchi, Nigeria pp. 315.

Abubakar, M.B., (2014). Petroleum Potentials of the Nigerian Benue Trough and followed by kaolinite, glauconite, montmorillonite, pyrite, illite, chlorite, hematite and calcite whilst major elements are dominated by $\mathrm{SiO} 2, \mathrm{Al} 2 \mathrm{O} 3, \mathrm{Fe} 2 \mathrm{O} 3, \mathrm{~K} 2 \mathrm{O}, \mathrm{CaO}, \mathrm{MgO}, \mathrm{Na} 2 \mathrm{O}$, $\mathrm{TiO}, \mathrm{P} 2 \mathrm{O}$ and $\mathrm{MnO}$ suggesting terrigeneus origin and continental shallow marine depositional environment. Trace elements concentration within the samples shows presence of $\mathrm{Ba}, \mathrm{V}, \mathrm{Rb}$, $\mathrm{Sr}, \mathrm{Ni}, \mathrm{Cr}, \mathrm{Ga}$ and $\mathrm{Cu}$ indicative of seawater rather than freshwater and suboxic to relatively anoxic marine environment. Consequently, the organic matter within the Turonian sediments of Jessu Formation were sourced mainly from terrigeneous and aquatic and, deposited under suboxic condition.

Anambra Basin: A Regional Synthesis. Natural Resources, 5(1), 25-58.

Adegoke A.K, Abdullahi W.H., Hakimi, M.H., Sarki Yandoka, B.M., (2014). Geochemical characterisation of Fika Formation in the Chad (Bornu) Basin, northeastern Nigeria: implications for depositional environment and tectonic setting. Applied Geochemistry 43, 1-12. 
BAJOPAS Volume 13 Number 1, June, 2020

Adegoke, A.K., Abdullah, W.H., Hakimi, M.H., (2015). Geochemical and petrographic characterisation of organic matter from the Upper Cretaceous Fika shale succession in the Chad (Bornu) Basin, northeastern Nigeria: Origin and hydrocarbon generation potential. Marine and Petroleum Geology 61, 95110.

Benkhelil, J., (1989). The origin and evolution of the Cretaceous Benue Trough (Nigeria).Journal of African Earth Science 8, 251-282.

Carter, J.D., Barber, W., Tait, E.A., Jones, G.P., (1963). The geology of parts of the Adamawa, Bauchi and Bornu Provinces in Northeastern Nigeria. Geological Survey Nigerian Bulletin 30, 53-61.

Galarraga, F., Reategui, K., Martïnez, A., Martínez, M., Llamas, J.F., Márquez, G., (2008). $\mathrm{V} / \mathrm{Ni}$ ratio as a parameter in palaeoenvironmental characterisation of non-mature medium-crude oils from several Latin American Basins. Journal of Petroleum Science and Engineering 61, 9-14.

Guiraud, M., (1990). Tectono-sedimentary frameworks of the Early Cretaceous continental Bima Formation (Upper Benue Trough, NE Nigeria). Journal of African Earth Sciences 10, 341 -353.

Guiraud, R., Maurin, J.E., (1992). Early Cretaceous rifts of Western and Central Africa: an overview, in: P.A., Ziegler, (Eds.), Geodynamics of Rifting, Volume II. Case History Studies on Rifts: North and South America and Africa. Tectonophysics, 213, 153-168.

Hakimi, M.H., Abdullah, W.H., Shalaby, M.R., (2011). Organic geochemical characteristics and depositional environments of the Jurassic shales in the Masila Basin of Eastern Yemen. GeoArabia 16, 47-64.

Hakimi, M.H., Abdullah, W.H., Alias, F.L., Azhar, M.H., Makeen, M.H., (2013). Organic petrographic characteristics of Tertiary (Oligocene-Miocene) coals from eastern Malaysia: Rank and evidence for petroleum generation. International Journal of Coal Geology 120, 71-81.

Hunt, J.M., (1995) Petroleum Geochemistry and Geology. W.H. Freeman, New York, 743p.

Johnson, M.J., (1993). The system controlling the composition of clastic sediments. In: M.J. Johnsson, A. Basu (Eds.), Processes Controlling the Composition of
Clastic Sediments, Geological Society of America Special Paper, 284, 1-19.

Nichols, G.J., (2009). Sedimentology and Stratigraphy, John Wiley and Sons, New York, pp. 452.

Nwajide C.S., (2013). Geology of Nigeria's Sedimentary Basins.CSS Bookshops Ltd., Lagos, Nigeria, 565 pp.

Peters K.E., Moldowan J.M., (1993). The biomarker guide: interpreting molecular fossils in petroleum and ancient sediments. Prentice-Hall, Inc, Englewood Cliffs, New Jersey.

Peters K.E., Walters C.C., Moldowan J.M., (2005). The Biomarker Guide: Biomarkers and Isotopes in Petroleum Exploration and Earth History, second ed., vol. 2. Cambridge University Press, Cambridge.

Roy, D.K., Roser, B.P., (2013). Climatic control on the composition of CarboniferousPermian Gondwana sediments, Khalaspir basin, Bangladesh. Gondwana Research 23, 1163-1171.

Sarki Yandoka B.M., Abubakar M.B., Wan Hasiah Abdullah, Amir Hassan M.H., Bappah U. Adamu, John S. Jitong, Abdulkarim H. Aliyu, Adebanji Kayode Adegoke 2014. Facies analysis, palaeoenvironmental reconstruction and stratigraphic development of the Early Cretaceous sediments (Lower Bima Member) in the Yola Sub-basin, Northern Benue Trough, NE Nigeria. Journal of African Earth Sciences 96, 168-179.

Sarki Yandoka, B.M., (2015). Sedimentary and organic facies characterisation of the Cretaceous sequences, Yola Sub-basin, Northern Benue Trough, NE Nigeria. Unpublished PhD thesis, University of Malaya, Kuala Lumpur, Malaysia.

Sarki Yandoka, B.M., Abdullah, W.H., Abubakar M.B., Hakimi, M.H., Adegoke, A.K., 2015a. Geochemistry of the Cretaceous coals from Lamja Formation, Yola Sub-basin, Northern Benue Trough, NE Nigeria: Implications for paleoenvironment, paleoclimate and tectonic setting. J. Afri. Earth Sci. 104, 56-70.

Sarki Yandoka, B.M., Abdullah, W.H., Abubakar, M.B., Hakimi, M.H., Mustapha, K.A., Adegoke, K.A., 2015b. Organic geochemical characteristics of Cretaceous Lamja Formation from Yola Sub-basin, Northern Benue Trough, NE Nigeria: Implication for hydrocarbon generating potential and 
BAJOPAS Volume 13 Number 1, June, 2020

paleodepositional setting. Arab. J. Geosci. doi 10.1007/s12517- 014-1713-3

Sarki Yandoka, B.M., Abdullah, W.H., Abubakar, M.B., Hakimi, M.H., Jauro, A., Adegoke, K.A., 2016. Organic geochemical characterisation of shallow marine Cretaceous formations from Yola Subbasin, Northern Benue Trough, NE Nigeria. J. Afri. Earth Sci. 117, 235-251.

Sarki Yandoka, B.M., Abdullah, W. H., Abubakar, M.B., Hakimi, M.H., Adegoke, A.K., Haruna, A.I., Yaro, U.Y., (2017). Hydrocarbon potential of Early Cretaceous lacustrine sediments from Bima Formation, Yola Sub-basin, Northern Benue Trough, NE Nigeria: Insight from organic geochemistry and petrology. Journal of African Earth Sciences 129, 153-164

Sarki Yandoka, B.M., (2019). Geochemical Investigation of Cretaceous Dukul Formation from Yola Sub-basin, Northern Benue Trough, NE Nigeria: Paleoenvironment, paleoclimate and tectonic setting. African Journal of Earth and Environmental Sciences 1 (2), 319 329.

Waples, D.W., Machihara T., (1991). Biomarkers for Geologists: a practical guide to the application of steranes and triterpanes in petroleum geology. American Association of Petroleum Geologists Methods in Exploration 9, Tulsa, Oklahoma.

Zarboski, P.F., Ugodulunwa, A., Idornigie, P., Nnabo, K., Ibe., 1997. Stratigraphy and structure of the Cretaceous Gongola Basin, Northeast Nigeria. Bulletin Centres Research Exploration and Production El fAquataine 21(1), 154185.

Zonneveld, K.A.F., Versteegh, G.J.M., Kasten, S., Eglinton, T.I., Emeis, K.-C., Huguet, C., Koch, B.P., de Lange, G.J., de Leeuw, J.W., Middelburg, J.J., Mollenhauer, G., Prahl, F.G., Rethemeyer, J., Wakeham, S.G., (2010). Selective preservation of organic matter in marine environments; processes and impact on the sedimentary record.Biogeosciences 7, 483-511. 